\title{
Wat Poramaiyigawas: The Reflection of Mon Identity during the Transition from Old to New Siam
}

\author{
Jirada Praebaisri \\ Ph.D., Candidate in Industrial Education, \\ Faculty of Industrial Education and Technology, \\ King Mongkut's Institute of Technology Ladkrabang (KMITL), Thailand \\ Koompong Noobanjong \\ Ph.D., Associate. Prof., \\ Faculty of Industrial Education and Technology, \\ King Mongkut's Institute of Technology Ladkrabang (KMITL), Thailand
}

Doi: 10.2478/mjss-2018-0159

\section{Abstract}

This research has studied Wat Poramaiyigawas with the objective to study Mon identity in Siam context through Buddhist architecture during the transition from Old to New Siam. The essence of this research is set upon the concept of Stuart Hall's Representation Theory which indicates that architecture is constructed with the purpose to express the creator's concept, with the method of studying related historical information and physical field study. Wat Poramaiyigawas had been abandoned before it was restored by the Mon immigrants in Thonburi Kingdom until it was later sponsored by Siamese aristocrats for major reconstruction. During the social transition from a conservative society to a modern one which had the Western world as the prototype, temple reconstruction or building of the Mon the subordinates of Siam where changes were taking place, the Mon had to follow Siamese aristocrats' view showing not only for the purpose of ideological significance of their belief or Buddhist function, but also was the venue for creating the ideological and conceptual meaning which were created symbolically through art and architecture according to views reflecting identity of the creator in that period than Mon people who were the real users.

Keywords: Reflection, Mon, Identity, Transition, Old to New Siam

\section{Introduction}

After Mon had been under Burmese colonisation in 1757, its people continuously migrated to Siam numerous times since Thonburi Kingdom to Rattanakosin Kingdom. Pak Kret, Nonthaburi City was assigned as one of the areas for setting up the community, therefore, Pak Kret was an important community and dan ${ }^{1}$ since Ayutthaya to Rattanakosin Kingdom, however, the city was abandoned after the war with Burma. When the Mon migrated in 1774, community was restored, temples were resurrected including Wat Chimphli Sutthawat, Wat Choeng Tha, Wat Palelai, Wat Klang Kret, Wat Poramaiyigawas, etc. for the purpose of religious activities especially Wat Poramaiyigawas which was an abandoned temple with no evidence of who the establisher was, yet some evidence shows certain historical significance, for example, during the reign of King Rama III, a number of titled monks were given financial support, having a patriarch as the superior, acting as an institute for

\footnotetext{
${ }^{1}$ Dan is named after the King's command to be operated as customs examining contrabands such as Dan Paknam. Nonthaburi city was located between Ayutthaya city and Chao Phraya estuary, it was the trade centre and rest area for foreigners as there were barricade and fort inspecting rafts and travellers.
} 
studying Dharma and Mon highest level of Buddhist Dharma, and interestingly, having granted the patronage for the reconstruction by King Rama $V$ in $1875^{2}$ which fell on the same period as the social transition of Siam, specifically people from the upper class who had power and influences on concept of changing the conservative society to a modern one.

Siam's conservative society was based on beliefs influenced by the Triphum ${ }^{3}$ which had an importance to system of value, way of life and social structure focusing on doing good deeds and omitting bad deeds, belief in reincarnation, etc. The belief which had declined consecutively allowed modern knowledge of the Western world to play parts in Siamese society along with the Western art. As said by Prakitnonthakarn (2007:19-20), there was an extensive amount of changes from the end of King Rama III reign to King Rama V reign, especially changes in opinion, value and worldview on social matters. This affected the Siam society that had had internal social development since early Rattanakosin and it was a transformation aligning with the pressure from Western influence. Siam social concept was expressed through types of art, notably Buddhist architecture, a unit compounded in the society which was utilised due to its main function and a matter which human gave definitions to, consequently was the representation or symbol according to the creator's meaning such as using symbols to reveal the creator, naming, layout, Western decoration expressing civilisation, etc. Roles of Siamese aristocrats in Wat Poramaiyigawas reconstruction during the transition from conservative society to modern society with Western prototype, therefore, gives explanation to the question whether Siam's incoming during the time had any effects on Mon identity as subordinate who were under context of the transforming Siam or was assigned to build to serve the Siamese aristocrats' view.

The description is based on Representation Theory by Stuart Hall (1997), saying the use of visual representation is a process with underlying significance production by the creator. There are noteworthy examples which have studied this matter including the research of Prakitnonthakarn (2007) considering architecture as a tool similar to sign language in reflecting history of the society in each era. This also corresponds with the research by Somboon (2005) seeing that architectural form and composition of Wat Benchamabophit are symbolic medium which reflects Buddhist cosmology of the governing class during the incoming of Western influences. This resulted in a reflection combining between virtuous and prestigious emperor and cultivated state. While the study of Naruepiti (2017) which considers Buddha images as objects in Buddhism that are restored or created to express certain meanings from political authority naming the imperially-adorned Buddha image at Wat Nang Nong, the temple of reign King Rama III is a representation of the king's image in ideological as a being with the highest merit and the centre at self. In addition, the research of Leksukhum (2001) which sees the influence of the West in the reign of King Rama III having effects on changes in worldview and social attitude which was reflected in mural with Buddha's disciples as main characters instead of kings.

From the aforementioned researches, they led as guidelines in describing case study that temples were not only built in accordance with people's belief in ideological significance or religious functions, but also to be an area in ideological meaning and concept that were created symbolically through art forms and architecture reflecting the creator's identity during each period of time. The structure of this description is divided into three sections: 1) worldview, concept, ideology and ideal in architectural work, 2) characteristics of Buddhist architecture 3) meaning in architectural under Siam context.

\section{Results of Investigation}

\subsection{Worldview, concept, ideology and ideal in architectural work}

\subsubsection{Conservative concept succession}

In Southeast Asia, the beliefs in Indra had a common theme on the basis of Hindu-Buddhism from

\footnotetext{
${ }^{2}$ Inscription on Wat Poramaiyigawas reconstruction on two stone inscriptions in Thai.

${ }^{3}$ Literally meaning the three realms of existence: heaven, earth, and the underworld.
} 
India. In ancient society, there were traces of Indra belief, a symbol of politics and ideology of the state in the northern state Lanna, in central state Kampangpetch and Sukhothai, in western state Burma and Mon and in Isan state all the way to Vientiane and Vietnam which were states with trade and diplomatic relations under federal governance. No social classes were evidently separated until the $19^{\text {th }}$ Buddhist century, states in the Chao Phraya River Basin began to transform into a complete feudal state with social and class sophistication, therefore, Indra belief was declined and replaced with Rama belief. It reflected the political form associated with the ancient Khmer state where filled with classes and sacred rituals and kings were demigods (Prakitnonthakarn, 2015:8486).

Siam in a conservative social context had the ideal political ideology of past leaders, as Santisombut (2013:291) said, the righteousness of power was often based on holiness, claiming a relation between a person who was a leader and a divine power, such as being a meritorious person or a demigod which was influenced by Hindu culture mixed with the Mahayana Buddhism of India through the Mon and Khmer by accepting the Mon Book of Dharma ${ }^{4}$ to be used as a pattern for the law of Siam as evidence was found during King Ramrachathirat of Ayutthaya reign and was used throughout the reign of King Rama IV of Rattanakosin. The essence was to determine the status of a king as a symbol of Dharma meaning a king who ruled with Dharma and fostered Buddhism. In the meantime, during a period of Ayutthaya era, Siam also accepted Devaraja ideology from Khmer where it was believed that the king was a holy figure. The king was Shiva or Vishnu avatar (Ocharoen, 1976: 147-153).

After Ayutthaya's second defect to Burma, Siam founded Thonburi and Rattanakosin consecutively. The country was in fragile state with financial crisis, yet, towns were built according to state capacity. Preeminently, during the early Rattanakosin between the reign of King Rama I and II, it was the era of capital reconstruction. Most artworks were created traditionally to Ayutthaya style (Saisingha, 2013: 16-17). Siam clearly showed its state ideology founding which covered the structure of ideas and beliefs as the foundation of Siam's art and architecture creation rooted from the "Triphumikatha cosmology". (Prakitnonthakarn, 2006: 37) This reflected the ideas and beliefs with absolution and precision from layout, shaping, architectural composition as well as painting. There was also the inheritance of such conservative concept as appeared in Phra Prang Wat Arun $^{5}$. Along with the use of symbols expressing architectural status utilised in kings' ceremony as sacred being, reflecting the status of kings in the past as demigods. It was expressed through images of Narayana, Indra and other deities found commonly on pediments in Ayutthaya and early Rattanakosin. It is explanatory that the state's use of symbols and Indra belief on royal institution were aligned with Mon's Book of Dharma.

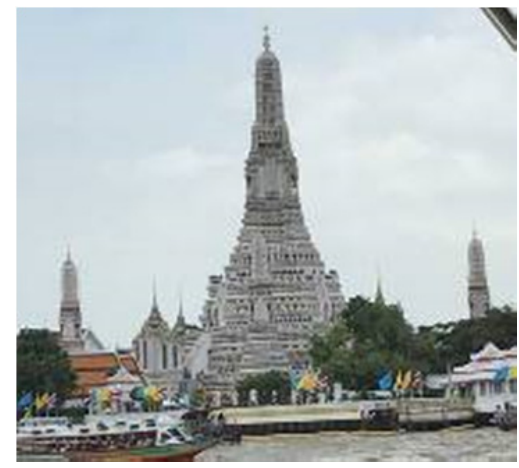

Figure 1: Pra Prang Wat Arun

Source: Authors

\footnotetext{
${ }^{4}$ Layout is derived from Manu Thammasat's ideals of India that discussed those Brahmanism but because Mon is a Buddhist. Thus, Manu Thammasat was chosen to apply only the principles of the rule of law to Buddhism and the reduction of the aspect of Brahmanism (Ocharoen, 1976: 148-149).

${ }^{5}$ The main pagoda at Wat Arun.
} 
Although, the Mon had their belief based on their own culture which was close to the Siamese naming Buddhism and Book of Dharma concept of governance adapted by Siam, Mon worldview, value and belief were under Buddhist convention which embodied rites in everyday life, substantially involving and relating to Buddhism believing in and worshipping spirits are components that were different from Siam as Ochareon (1976: 78) said, when the Mon migrated to Siam from Ayutthaya to Rattanakosin, communities were established and temples were restored for religious ceremonies that was consistent to conservative cultural traditions. It showed that Mon and Siam were different in terms of art and architecture. Mon people often adhered to Buddhist principles and inherited the connection between Buddhist history in Mon state, whether it was the creation of pagodas and swan pillars conforming to the legend of Hanthawaddy city and the worship of the sacred relics that Mon people gave respect to. As Tingsanchali (2011:283) said, pagoda pattern built in Mon community was likely resembled to significant examples including Shwedagon Pagoda and Sule Pagoda, the use of Bot Pae of Mon clergy in Siam after Kalyani Sima pattern ${ }^{6}$ as seen on mural of the scripture hall of Wat Bowonniwet as well as practices and restrictions of cultural rites, such as restrictions on access to Buddhism for secular women ${ }^{7}$, etc. However, it may have been the limitation as immigrants, the construction or restoration of the temple was not always based on the same pattern. As said by Chaturawong (2011:17), the Mon who migrated from lower Burma and settled in central Siam built Buddhist temples with Siam architectural style, for instance, restoring Siamese abandoned temples, the original characteristics, pagoda and ubosot were remained, not constructing pagodas according to their ideology as seen in Wat Palelai and Wat Klang Kret. In case of newly-constructed temples like Wat Koh Paya Jeng, the pattern was after King Rama III's style.

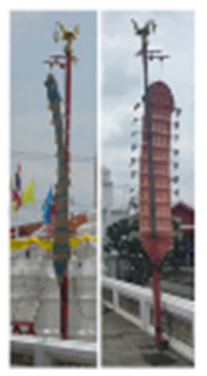

Figure 2: The swan pillar Source: Authors

Figure 3: Shwedagon Pagoda, Rangoon

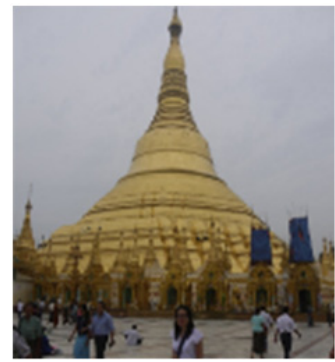
Source: Authors

\footnotetext{
${ }^{6}$ Ordination hall named Kalyani Sima, similar to the river monks were ordained by Phra Chao Dharma Chedi with the purpose to purify Buddhism and all monks are under the same practice. Twenty-two Thera monks were ordained by monks in Ceylon to have pure Mon monks and returned to be ordained as Mon monks like Lanka. Those Thera monks were re-ordained in a medium-sized house in the middle of Kalyani canal. Sima Kulyani is a temple. "Sima" is Burmese term for temple.

${ }^{7}$ Secular women restrictions including not touching monks directly, not even close relatives and many restricted areas for women, including, monasteries, vihara and monk dwelling and ritual area (Banjun, 2007: 170).
} 


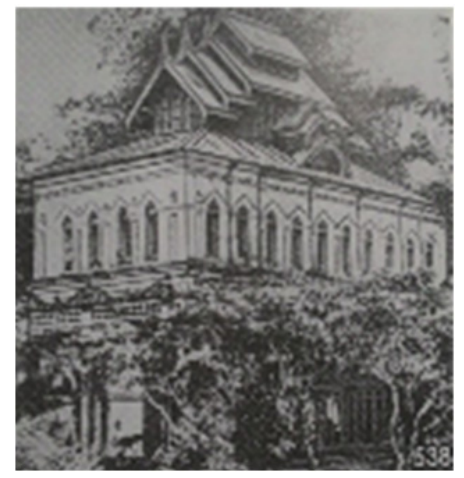

Figure 4: Kalyani Sima, Pego

Source: Chaturawong, 2011

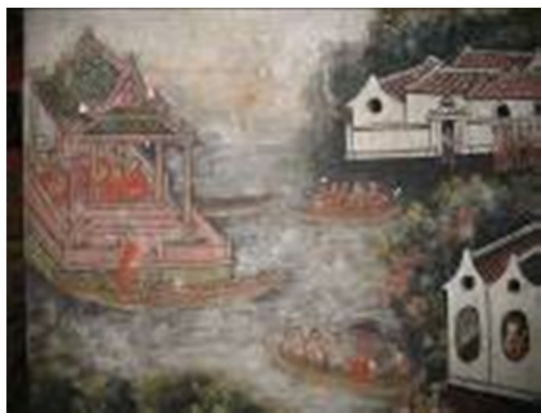

Figure 5: Bot Pae mural at Wat Bawornniwet, Bangkok Source: Soomjinda, 2014

Siam since the reign of King Rama III had been a declining in the use of force in occupying major cities, instead, giving importance to trades, yet, remained the concept of centralisation as evident in creating symbols expressing power over major cities including confiscating local Buddha images to Bangkok and erecting permanent structures as memorials of events as well as the remaining ideal of virtuous and prestigious king image which can be seen in fine art expressing the great emperor. (Naruepiti, 2017:81-83) However, during the reign of King Rama III, antiquity founding concept was changed in both traditional style and royal style ${ }^{8}$. Especially, ideology and royal initiatives in establishing temples to be the centre of the universe such as creating the adorned Buddha image of Wat Nang Nong. Upon entering the reign of King Rama IV, though Western civilisation played such important role in this era, some of fine art expressed the reversion to traditional style such as layout patterns expressing the Sukhothai and Ayutthaya style, Lanka-styled pagoda expressing the reversion to Buddha's disciplines for monk hood which were the acts of Dhammyuttika founded in the reign of King Rama $\mathrm{II}^{9}$ as seen in Wat Chaloem Phrakiat Worawihan which later in the early time of the reign of King Rama $\mathrm{V}$, there were fine art with traditional style with the form inherited from the reign of King Rama IV.

\footnotetext{
${ }^{8}$ The two building models are the same permanent building. Large and spacious. The pillars are large and add pillars to support weight. There are also variations in the layout in (Saisingha, 2008: 9-10).

${ }_{9}^{9}$ Monk reformation and "Dhammyuttika" founding in the reign of King Rama III was caused by the Crown Prince (King Rama IV) while was in monkhood witnessed undisciplined monk and finally met Mon monks with respectable practices.
} 


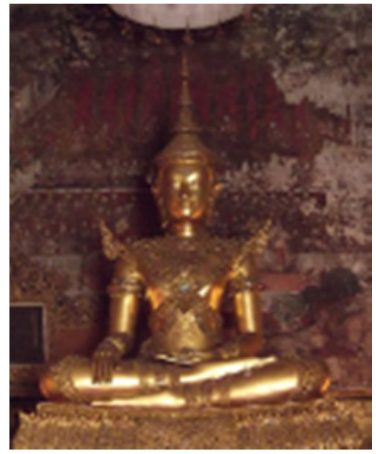

Figure 6: Adorned Buddha image at Wat Nang Nong, Bangkok Source: Saisingha, 2013

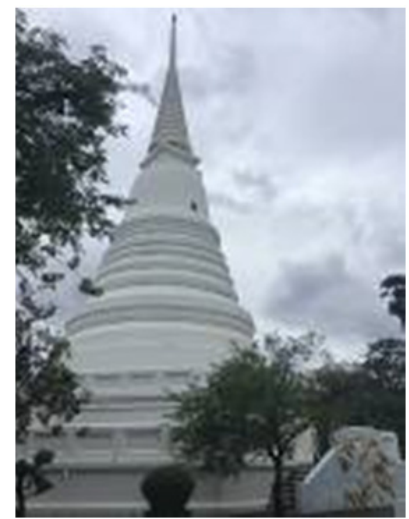

Figure 7: The main pagoda at Wat Chalermprakiat Worawihan, Nonthaburi Source: Authors

\subsubsection{Incoming of modern concept influences}

Early Rattanakosin state and society experiences drastic changes from Ayutthaya in numerous aspects, especially financial transformation of the Siamese aristocrats which was the main factor in affecting them to have modern worldview, value, taste and belief, resulted in self-confidence of their own ability which caused changes in the state and social cultural transformation (Sattayanurak, 2015:292). It was evident in architectural art which expressed realism as more dimensions were seen on murals of Phutthaisawan Throne Hall in the reign of King Rama I, yet, clearly enough, until the reign of King Rama III, the country was spared from wars and battles with presence of international trade, foreign influence on art were increased, especially, Chinese art influence, resulted in royal preferability (Saisingha, 2013:17) including Chinese-style Tavaraban ${ }^{10}$. With the increasing Western influence after the victory of the British military over Burma in 1825 and China in 1840 (Prakitnonthakarn, 2007: 111), it could be said that it was the start of transformation from conservative to modern state and opened up for the concept of the West's science and modern standard. Initially, it was limited to only one interest focusing on modern technology (Thavornthanasarn, 1987: 124) naming modern medicine and shipbuilding technology.

\footnotetext{
${ }^{10}$ Tavaraban is from the word "tavarn" means gate and "barn" means to protect or govern. "Tavaraban" means gate guard which is located at door panels, the entry and exit way, window opening or stair railing.
} 

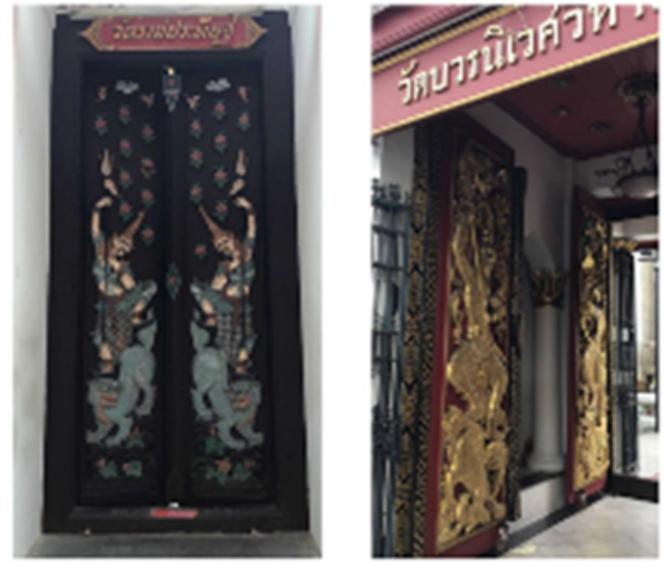

Figure 8: Chinese style Tavaraban

Source: Authors

Later, in the reign of King Rama IV, the time of Western civilisation, the popularity of creating works in King Rama III style slowly disappeared. Some artworks reverted to the traditional style while the others embraced the Western influence which expressed the idea of giving importance to human identity in terms of individualism. Examples can be seen as Sattayanurak (1995:30) explained, the Siamese aristocrats had different way of thinking which was the awareness of imagination. The belief in the Triphum began to deteriorate. Mount Meru was no longer the centre of the universe. The world consisted of states with connecting territories. No state was superior to all the other states. This came to the realisation that Bangkok was not the one and only great state existing. Symbolic expression reflecting the monarchy in the past that emphasised on the concept of demigod lost its popularity. The change from using the king's image on symbolic pediments to the symbol which implied the creator or whom the work was created for specifically. Moreover, the use of royal emblems or any other emblems was legitimate, there were uses of medallion symbols ${ }^{11}$. In the reign of King Rama IV, evidence was found that Napoleon III sent an insignia to pay homage which was considered a new tradition for kings to be decorated with insignia. Siam was the first country in Southeast Asia region to create and decorate with royal insignia. This implies the understanding and vision of King Rama IV. However, the royal insignia is the symbol of honour and token of appreciation the king created to be given to persons with positions or persons with responsibility to the country to be seen in accordance with their rank and nobility.

In the reign of King Rama V, an era of art transformation due to Western culture influence, learning of foreign culture was at the highest rate than any era through diplomatic relations including royal excursions to Europe and Asia, exchange of royal letters, ambassadors presenting royal insignia and tributes, etc. (Paknam, 2000:55) The Siamese aristocrats' interest in Western culture allowed the culture to become the highness of expressing civilisation as Prakitnonthakarn (2003:112) said, the lead to transformation under the influence of the word "civilisation" which widely infiltrated into every section of the society affecting culture, politics, art and architecture, including all major cities, the Mon who had been a part of Siam community were also influenced by the Western culture as seen on sculptures wearing Western uniforms decorated on pagodas on ship-like base of Wat Suthapoch which was built in the reign of King Rama V by Chao Chom Manda Son Klin who was of Mon ethnicity.

\footnotetext{
${ }^{11}$ The first royal emblem was introduced in the reign of King Rama IV in 1857 named "Dara lyarapot"( Secretariat of the Cabinet, 2003: 8).
} 


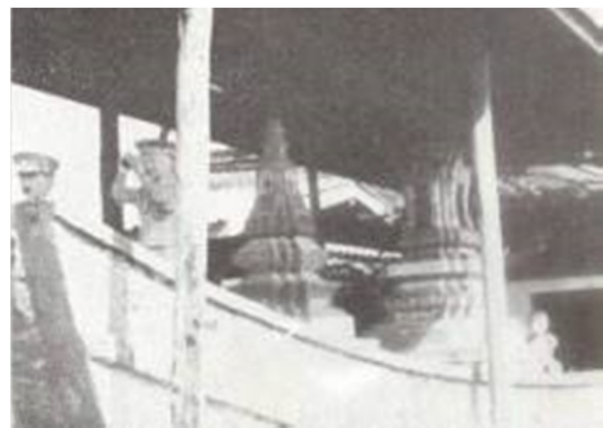

Figure 9: Pagoda at Wat Suthapoch, Bangkok

Source: Mon studies, 2015

Prakitnonthakarn (2007:131-137) also gave an opinion on architecture in the reign of King Rama V that it was the only era attempted to combine Western style and traditional style such as Wat Atsadangnimit. While in the reign of King Rama IV, Western architecture was evident only on buildings with Western utility purposes including the throne hall in Phra Apinaoniwet. Temples or other architecture which were used in traditional customs were still in traditional style or royal style without any Western architectural influence. Even in the reign of King Rama VI, Western architectural style was not mixed in any work with traditional customs. Instead, it was the traditional architectural style that was mixed with or adapted to Western-style architecture, such as auditoriums and schools.

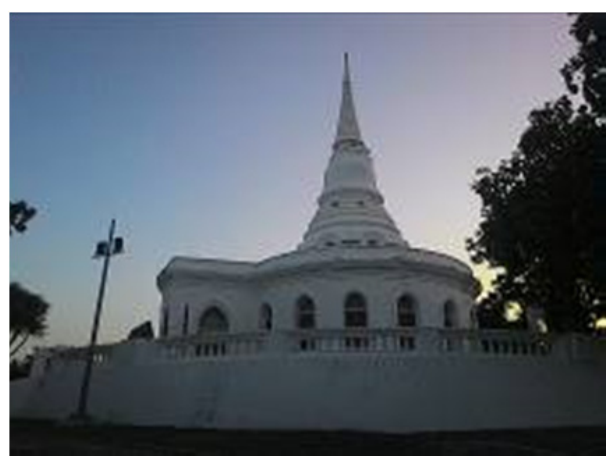

Figure 10: Wat Atsadangnimit, Chonburi Source: Authors

\subsection{Characteristics of Buddhist architecture}

Wat Poramaiyigawas, originally named "Wat Pak Aow" or in Mon "Kiew Mu Kia Teng" meaning spiky head temple, located on the corner of Koh Kret with perimeter connected to the Chao Phraya River, Khlong Lad Kret and public waterway. The temple was patronised by King Rama $\mathrm{V}$ for restoration, under the control of the Siamese aristocrats from 1875-1884 to honour Her Royal Highness Princess Grandmother Lamom and for monks to perform Mon ceremonies. Siam in that time was the early reign of King Rama $V$ where changes in the internal politics from old to new party $^{12}$, combined with the influence from the West, resulted in noteworthy forms and characteristics whether it is in painting, sculpture or architecture. The three main important forms of combination

\footnotetext{
${ }^{12}$ Regent position termination of the Bunnag family, the conservatives governing the country.
} 
are: Siamese, Western and Mon. What was repaired and additionally built during the reign of King Rama 5 can be summarised (Paknam , 2003: 86-88.) as follows.

\subsubsection{Layout}

Layout arrangement was to separate the Buddhist civilian section and Buddhist monk section ${ }^{13}$ by setting the ubosot ${ }^{14}$ as the core centre in front of the pagoda in traditional style compatible to the style of the reign of King Rama IV. The walls surrounding the ubosot are with four entrances, one on each direction with Sema door facade on all four corners of the wall. A new fence was installed around the new pagoda. Entering and exiting points were on both sides of the temple. Sermon hall was relocated at the south and waterfront pavilion was moved to the north where the monk dwelling was on the side of Chao Phraya River. Footpaths were built to connect all areas. It is noteworthy that the original Mon pagoda was isolated and situated by the river. This layout is similar to the one of Wat Chaloem Phra Kiat Worawihan instructed to be built in the reign of King Rama III and was completed in the reign of King Rama IV.
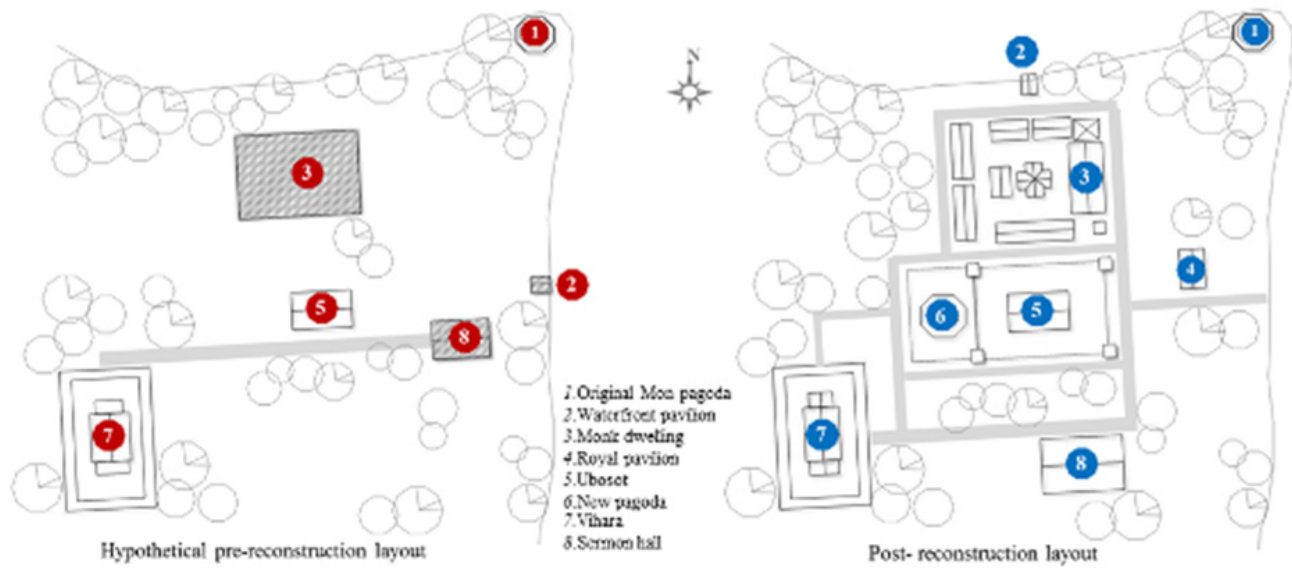

Figure 11: Layout of Wat Poramayikawas

Source: Authors

\subsubsection{Form of Buddhist architecture and its composition}

The renovated ubosot, increased in size, was situated on an elevated foundation. There are one door in the front and another two in the back. The building has columnar around under the balcony. There is no moulding decoration on the columnar nor corbel. The roof is a double-level. The pediment was brick-laid, cemented and decorated with confederate rose vine design stucco. The superstructure was built with the royal style of King Rama III. Interior wall, exterior doors and windows are decorated with Western-styled vine design. Gilded door and window arch frames are of royal hall-style decorated with glass. Interior doors and windows are painted with gilded watermark. The floor and edges of the wall inside are laid with patterned tiles. The mural inside the ubosot depicts the history of Buddha as well as monk activities, similar to the reign of King Rama IV which shows the combination of Thai-traditional and Western style through sceneries with realistic dimension. Balcony flooring is laid with marble from abroad. Low wall surrounding the ubosot was

\footnotetext{
${ }^{13}$ Buddhist civilian section means the area setup for religious ceremonies for both monks and civilians including pagoda, Buddha image hall, ubosot while the Buddhist monk section consists living area, dining hall, toilet, kitchen, pavilion, etc.

${ }^{14}$ Meaning the ordination hall.
} 
brick-laid and cemented. Grilles and doors are made of cast-iron with Art Nauveau design. Capitals of the doors are decorated with European-styled cast iron plant pots. Royal seals of King Rama $V$ is decorated on the pediments on the exterior of doors and windows.
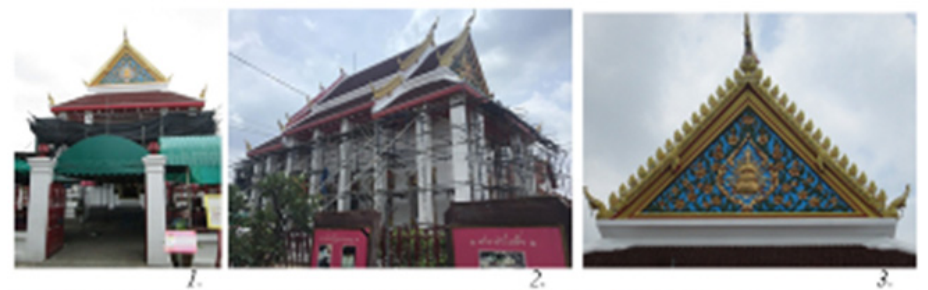

1-2.Exterior of the ubosot

3.The pediments

4. Interior of the ubosoc

5.The ceiling isside

6.8. Door and wisdow

9. Grille and door
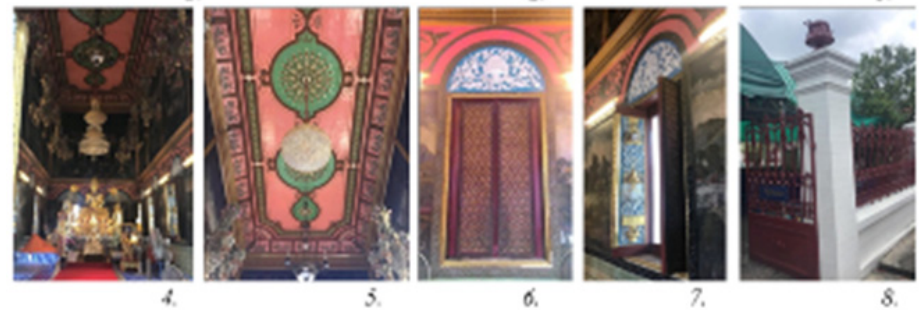

Figure 12: Interior and exterior design and architecture of the ubosot Source: Authors

The longer and higher renovated vihara ${ }^{15}$ is situated on an elevated foundation with two doors in the front, its superstructure and ceiling are made of teakwood. Its roof is covered with interlocking tiles. Columns are brick-laid and cemented. Its floor is laid with European-imported marble. The ceiling inside is painted with insignia of Pathom Chulachomklao watermark covered in silver and gold in total of 13 seals. Window facades are in Thep Phranom and floral design. The front of the vihara in the north situates Mon marble Buhhda image. The back of the vihara in the south situates the Buddha image of Nonthaburi province. The balcony around the hall was removed and expanded with the use of bricks and cement to build the Western architectural style arch. The door of the balcony at the east side painted with Tavaraban design similar with combined characteristics of Thai and Chinese angels. Facial feature and weapon are of Chinese characteristics, but the clothing is Thai (Saisingha, 2013: 424).
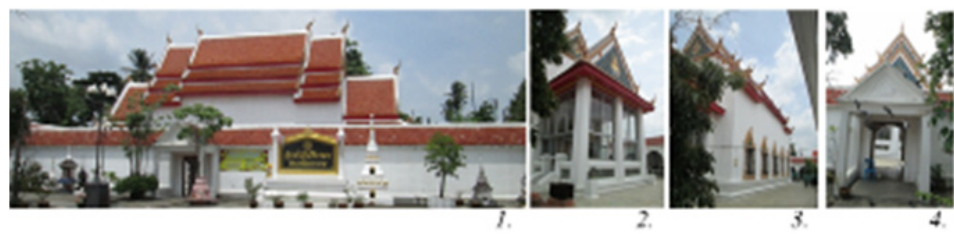

3-3.Fxterior of the vihara SEntrance of the viltara

5.6. The balcony around the hall

7.Tavaraban

8.9. Window and door

10.Mon marble Buhbda inage

11. The Buddha image of

Nonthabuti province
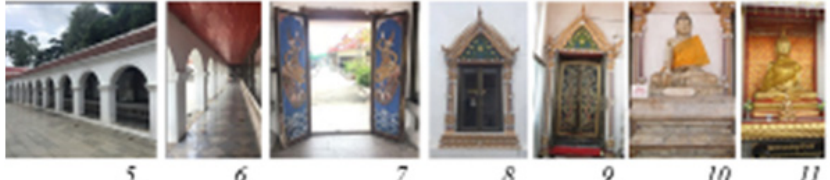

12. Interior of the vihat

Figure 13: Interior and exterior design and architecture of the vihara Source: Authors

\footnotetext{
${ }^{15}$ Meaning Buddha image hall.
} 
The 1878 newly-constructed Mon pagoda situated in the back of the ubosot with its five-tiered umbrella peak is an expanded octagon slope base without minor pagodas decoration at the corner of each tier (Saisingha, 2014: 165-166). The pagoda is undecorated and located on the Prataksina base decorated with angle pattern around base level, similar to fret pattern with a staircase on the west. There are stucco arch frames from floor to lower ground on three directions except the south. In front of the arch, there are offering tables in the north and the south. The wall around the pagoda except the back side of the ubosot is railing made as arch of glazed tiles. The research of Hongsakaola (2005: 25) offers an opinion that the pagoda form is a combination of Siamese art which could have been the familiarity of the designer or the original pagoda pattern to express the relation between the new construction and the original one. As there was no demolition or renovation of the original pagoda. Whereas Phinthuphan (2004: 38) argues that the pagoda is a replica of Shwemawdaw Pagoda or Phra That Mutao.
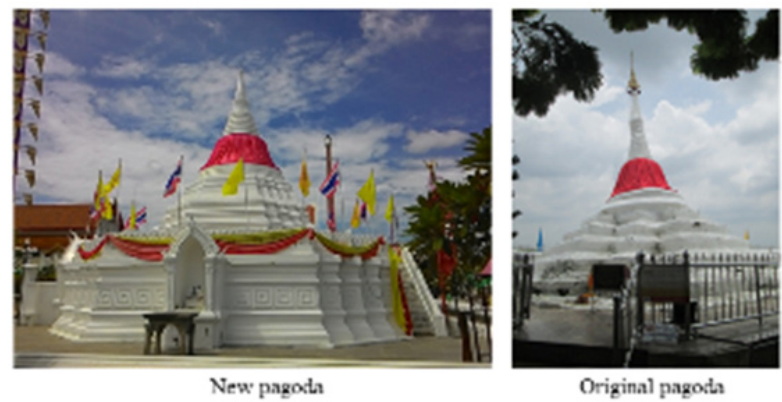

Figure 14: The pagoda at Wat Poramaiyikawas

Source: Authors

The original sermon hall was removed and rebuilt at the south side of the ubosot entirely of teakwood. Verada around floating columns is of Mon style. Around the balcony are brick-laid cemented marble tiled railings with two-sided wooden staircases. On the east and the south is platform seat for monks without cover. Wooden-plate decorated window arch is of Western-styled fretwork.

Monk dwelling area was built by bricklaying and cement in Mon style on the north side. The waterfront pavilion in front of the sermon hall was removed and rebuilt at the dock at the north side next to monk dwelling area adjacent to Chao Phraya River. Connecting footpaths are present from monk dwelling area, ubosot, sermon hall, vihara, path in front of the ubosot down to Klong Lad Kret and a colonial-styled royal pavilion was constructed in front of the ubosot.
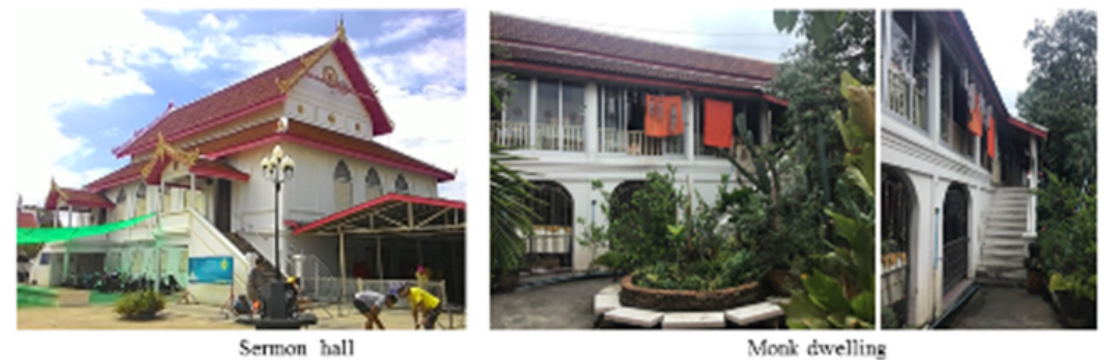

Monk dwellins

Figure 15: Sermon hall and monk dwelling Source: Authors 


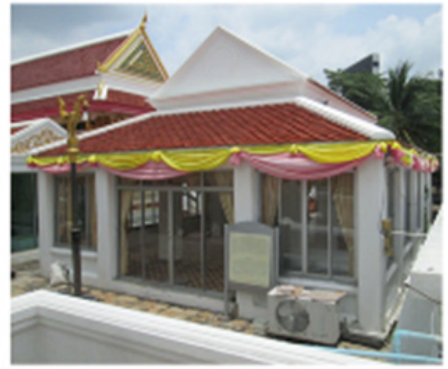

Exterior

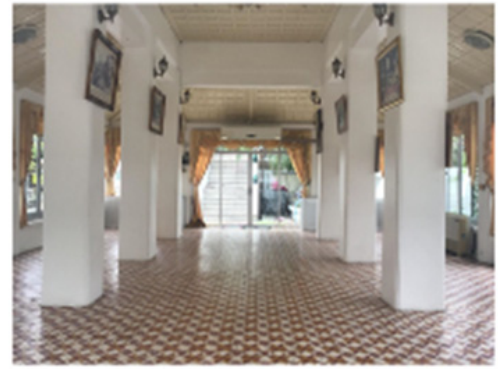

Interior

Figure 16: Royal pavilion

Source: Authors

In addition, modification was made on the principle Buddha image, disciples and angels inside the ubosot to be more realistic according to a new concept which is semi-realistic or realism influenced by the Western culture of creating lifelike image. The base of Buddha image is a plastered and gilded with glass decoration on top of brick-laid and cemented foundation decorated with imported marble. Nonthaburi provincial Buddha image was also built and named "Phra Nonthamunin" with original design from the principle Buddha image in the ubosot.

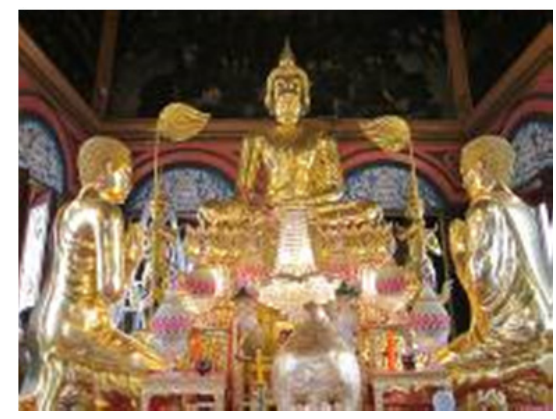

Figure 17: The principle Buddha image, disciples and angels in the ubosot Source: Authors

\subsection{Meaning in architectural under Siam context}

In the early stage of Wat Poramaiyigawas restoration by the Mon, it was created via religious aspect and different belief from capital culture, resulting in a unique work including idealistic pagoda creation and utility of the existing state of the temple. Until the Siamese aristocrats' sponsorship for reconstruction, though for the Mon people, it was restored under the concept and desire of the Siamese aristocrats. During the time of Siam being under impact of social, political, economical and Western influence, this led to cultural interventions and modern ideas after the artistic taste of the Siamese aristocrats, whether it be the expansion of space, new layout and the use of symbolic expressions in terms of power which was unlike the concept of the Mon people that was to express the meaning of Buddhist scriptures or for actual use. It became the model shown below.

\subsubsection{Displaying purpose through names}

Naming after the purpose of a creation is commonly used as symbolic tool of remembrance by naming in relation to the creator or those with positions or statuses they wanted to remember or 
places to be remembered. Local people had called the temple "Wat Ban Laem" or the Mon called it "Phia Mu Ha Teng" which means temple with spiky head because of its physical appearance, however, when the Siamese aristocrats took over, its name was changed in honour of Her Royal Highness Princess Grandmother Lamom into "Wat Poramaiyigawas" (borom+iyiga+awas) which means temple of grandmother. This is a naming method clearly to express significance in naming with clear representation of certain subjects or people. It is commonly found among temples built or reconstructed by the Siamese aristocrats including Wat Benchamabophit, Wat Makutkasatriyaram, Wat Ratchaorotsaram, etc. While the Mon often called names that explain the physical features of the area such as Pia Alat (Wat Saothongtong) meaning western temple because of its location on the west side of Koh Kret. The Mon naming was always with religious significance rather than individual such as the naming of Phra That Mutao built in Siam or using the original name of the village they used to live in Mon state such as Kwan Aman and Kwan Alat.

\subsubsection{Meaning creation through symbol}

The use of royal seals on ubosot pediment and vihara in the form of a coronet. The use of King Rama $V$ royal seals ${ }^{16}$ on door and window panels in the shape of a coronet with illuminating aura on ornate tray embedded with pieces of glass, underneath found three-headed elephant inside a shield signifying northern, southern and central Siam. On the left and right side are Rajasi (a lion) and Kotchasi (an animal with a lion's body and an elephant's trunk), signifying Rajasi seal representing Chancellor and Kotchasi seal representing the grand commandant. Both parties' duties were to defend the kingdom and sustain the monarchy, reflecting Siam's old governance structure of the beginning of the reign of King Rama $\mathrm{V}$ in transitioning to transformation era. From the variation of the symbol changes from generation to another (Soomjinda, 2014:168) as well as religious architectural decoration with royal seals that was influenced by the West replacing the original symbolical system in traditional architecture as seen in the use of Pathom Chulachomklao Wiset ${ }^{17}$ royal emblem which replaced the star-covered ceiling mural in the ubosot. The significance of the royal emblem Prakitnonthakarn (2007:127-129) said is the new way of celebrating the king's honour according to value of civilised countries where the identity of the creator is expressed after humanism concept. Along with the use of royal seal which was evident in the reign of King Rama IV with the purpose to identify the creator which differed from the conservative method of using symbols through representation without specific identification of certain individual such as Garuda emblem and Indra, but it could be connected to the status of the creator. It can be said that symbols apparent on the pediment and door and window panels as well as royal emblem drawing instead of star-covered ceiling mural inside ubosot and vihara, all have the relevant meaning to glorify the greatness of King Rama $\mathrm{V}$ which signifies the basis of Westernised modern concept declaring power, duty and responsibility, the three elements expressing loyalty to the king. It is the submission of allegiance and service to the country, what are their duties and responsibilities, as well as clearly a marking of authority over the kingdom of Siam through symbols. While Mon people only used swan pillars located on the temple ground, a symbol of the legend of Hanthawaddy city of the Mon. It reflects the existence of Mon people outside their motherland through swan symbol, not showing any specific symbol of any creator.

\subsubsection{Layout modification}

Reversion to Siam's conservative ideology during Sukhothai and Ayutthaya Kingdom is shown by using the architectural layout where the pagoda was preferably built in the background in the same direction as the main ubosot. There were also changes in the original utility space which was related to Mon way of life by dismantling the waterfront pavilion and the sermon hall in the front of

\footnotetext{
${ }^{16}$ Was the King's seal used in early King Rama $V$ reign consisting of three-headed elephant in the centre of the arm, on the sides, Kotchasi and Rajasi stepping on a globe carrying nine-tiered umbrella, above is a coronet placed on ornate tray embedded with pieces of glass (Paknam, 2003: 87).

17 Highest rank of royal emblem sash.
} 
the ubosot to another location. The layout reorganisation also separated the Buddhist civilian section and Buddhist monk section. New fencing indicates the perimeter of the ubosot and the new pagoda and setting entrance and exit point of the vihara by connecting all areas with footpaths to demonstrate a well-organised space. While the separation of the original Mon pagoda by the river signifies the difference of Mon temple construction and architectural layout as Jiratatsanakul, Jaturawong \& Supasiri (2004:296) said, layout was planned with the consideration that the main pagoda was the main building, situated independently without relation to other buildings, but it was usually arranged to be in a position relative to the passageway, such as facing the river without a fixed pattern in accordance with the example of Mon culture in their homeland. This corresponds with Chaturawong (2011:72) explanation, temples in Mawlamyine city usually have free layout, having the principal monastic dwelling as the core centre without Buddhist civilian and Buddhist monk section separated, therefore, the new layout indicates the conservative frame of thought evidently reflecting the power and the glory of the king over the Mon people by having the ubosot and the centre in front of the newly-construct Mon pagoda. With the reaffirmation of degrading the value and importance of worshipping area which was the symbol of Mon people by disconnecting the path leading to the original Mon pagoda located by the river.

\subsubsection{Reconstruction to integrated form}

The reconstruction was done under the control of Siam with integrated design between Mon traditional and Western style, a combination of conservative belief which desired to show power and nobility of kings, for example, reconstructing by retaining the traditional Siamese style of values as a good patron of religion, and modern concept which inspired to express the country's civilisation such as Western-style construction and decoration. This worked effectively in demonstrating Siam's power to major cities by using religious space as the relationship bonder of Mon and Siam. By building the temple with Mon ideology and insisting that Mon monks stay in the temple during lent to strictly perform activities according to all Mon customs showed that the use of important local religious architectural symbolic medium can well indicate the state territory.

\section{Conclusion}

This research shows the reflection of Mon identity transformation during Siam's transition through form of Buddhist architecture of the Mon who were under Siam's governance as immigrants which can be described as follows.

1. Concept that affects the architectural art in Siam had been developed since Sukhothai to Rattanakosin is of a conservative one. Both Mon and Siam shared the base idea of a similar culture from India's Hindu-Buddhism. However, Mon people often adhered to Buddhist principles and inherited subjects related to the history of Buddhism in Mon state while Siam had the ideal political ideology of leaders with sacred power, resulting in different forms of Buddhist architecture. Later, early Rattanakosin state and society was experiencing drastic changes, especially with Chinese and Western influence respectively, conservative state started to transform into a modern state, it was replaced by scientific concept and modern Western standard. Siamese aristocrats paid attention to the Western culture, it became noble culture reflecting civilisation. Under the expanding influence of the term "civilisation", all parts of the society were touched by it, even among the Mon who had become a part of Siam.

2. Wat Poramaiyigawas architecture appeared during the transition from Old to New Siam has features that show the link of combination of Siamese traditional, Mon style and modern Western style. The form of architecture as well as decorative art reflect the architecture in the reign of King Rama V. Overall, there was a different image representation from the precedent reign, resulting in the change of preferability in the royal art, though remaining in the traditional Siamese style according to the royal art style of the reign of King Rama III and King Rama IV such as layout. In the meantime, Western architectural style played an increased role as the representation of civilisation such as 
open plan to reveal Western decorative style, the use of royal symbol identification, etc. Nonetheless, Mon architectural form was not neglected as it was created under the newlyset form as seen on Mon pagoda layout to be an element in the back of ubosot where it is the core centre of the temple.

3. Giving definition through architecture of Wat Poramaiyigawas by its name, symbolic images, layout or renovation is the reflection of the way of thinking of Siamese aristocrats which had been through the process of definition and value that evidently influenced the Mon being under Siam context through Buddhist architecture. It can be said that the reconstruction of Wat Poramaiyigawas architecture is the representation of reconstruction initiator in founding power through architectural art by deploying Siamese form that was the centre of beauty and accuracy standards based on the aristocrats. The Mon had to accept Siamese model which was changing accordingly to current trends despite the fact that the Mon had their own model.

Architecture can be considered as a reflection of conception as defined by creators which shows a complex interaction between the creator and the environmental context. The Buddhist architecture of Wat Poramaiyigawas was based on the establishment of power and bond in the Mon community in the early time of the reign King Rama $V$ through spatial relationships having Buddhist faith as the link by using conservative paradigm focusing on the glory of the king through new interpretations due to the adaptation and assumption adjustment to match with currents of the inflowing Western influences at the time. This reflects the concept of Siamese aristocrats in developing their civilisation along with the integration of the Siamese and Mon.

\section{Reference}

Bunjoon, O. (2007). Mon Woman in the Royal Court of Siam during Ratanakosin Period 1782-1932. Thesis of Master Degree of Arts Program in Thai History. Bangkok: Srinakharinwirot University.

Chaturawong, C. (2011). The Architecture of Mon Buddhist Monasteries in Lower Burma. Bangkok: E.T.Publishing.

Hall, S., ed.(1997).Representation : Cultural representations and signifying practices.London: Sage.

Hongsakaola, N. (2005) Main Pagoda Mon-Mynmar Style of Wat Poramayikawas Pak kret Nonthaburi. Project of Bacherlor Degree of Art History. Bangkok : Silpakorn University.

Jiratatsanakul, S., Jaturawong, C., Supasiri, C. (2004). Architectural Forms of Buddhist Temples in Local Communties.Local Wisdom in Houses, Communities and Cultural Ecology for Sustainable Living of Thai People in Western Region.Sub-Project 4. Silpakorn University Research and Development Institute 2004. Nakon Pathom: Silpakorn University Press.

Leksukhum, S. (2001).The Mural Paintings in King Rama III Reign : Change of Thought Change in Expression.Research Sponsorship from National Research Council of Thailand. Bangkok : National Research Council of Thailand.

Mon studies. (2015). The Junk that Carried Tripitaka from Jambudvipa to Suwannabhumi. [Online] Available: https://web.facebook.com/RamannMon/posts (May 5, 2015)

Naruepiti, W. (2017). Politics in Buddha Image. Bangkok: Matichon.

Ocharoen, S. (1976). The Mons in Thailand: an analysis of their status and role in Thai society from the mid Ayudhya to the early Ratanakosin period. Thesis of Master Degree of Art. Bangkok: Chulalongkorn University.

Paknam , N. (2000). The Mural Paintings at The Palace. Bangkok : Muang Boran.

Paknam , N. (2003). Wat Poramayikawas. Bangkok : Muang Boran.

Phinthuphan, H. (2004). History of Nonthaburi. Bangkok: Odean Store.

Prakitnonthakarn, C. (2003) From Old- Siam to New-Thai: Social and Political Meanings in Architecture During 1892-1957. Thesis of Master Degree of Architecture. Bangkok: Chulalongkorn University.

Prakitnonthakarn, C. (2006). Society and Politics in Architecture from Old Siam to New Siam 1851-1947. Journal of Architectural History and Thai Architecture, 3(4) , 37

Prakitnonthakarn, C. (2007). Politics and Society in Siam's Architectural Art during Thai Nationalism. Bangkok: Matichon.

Prakitnonthakarn, C. (2015). Politics in Architecture during King Rama I. Bangkok: Matichon.

Saisingha, S. (2008). Artisan in King Rama III reign. Bangkok: Matichon.

Saisingha, S. (2013).Buddhist Art in Rattanakosin Artist Development and Altered Concept. Bangkok: Muang Boran.

Saisingha, S. (2014). Myanmar Art. Bangkok: Matichon. 
Santisombut, Y. (2013). Human and Cuiture. Bangkok: Thammasat Printing House.

Sattayanurak, A. (1995). Changes in Worldview of Thai Aristocrats from King RamalV reign to 1932. Bangkok: Chulalongkorn University Press.

Sattayanurak , S. (2015). A Research to Construct New Knowledge of "Thai Social History". Bangkok : The Thailand Research Fund

Somboon, T. (2005). Symbolic Significance in Wat Benchamabophit Dusitvanaram. Ramkhamhaeng Research Journal of Humanities and Social Sciences, 8(2), 74-89.

Soomjinda, P. (2014). Phra Jomklao Decoding. Bangkok: Matichon.

Thavornthanasarn, W. (1987). Thai Leaders in King Rama III with Western Culture Acceptance, Art \& Culture Magazine, 8(11), 116- 128.

The Secretariat of the Cabinet. (2003). Thai Royal Decoration. Bangkok: Amarin Printing \& Publishing.

Tingsanchali, C. (2011) The New Issues about of Pagoda Mon-Mynmar Style in Thailand. Research Sponsorship from Silpakorn University Research and Development Institute. Bangkok: Silpakorn University Research and Development Institute. 